\title{
Linkage Disequilibrium
}

National Cancer Institute

\section{Source}

National Cancer Institute. Linkage Disequilibrium. NCI Thesaurus. Code C16798.

Nonrandom association of linked genes; the occurrence of some genes together, more often than would be expected based upon their physical separation, presumably because the combination confers some selective advantage. 